University of Nebraska - Lincoln

DigitalCommons@University of Nebraska - Lincoln

\title{
Nutrient Utilization and Diet Preference of American White Pelicans Consuming Either a Mono- or Multi-Species Diet
}

Treena L. Ferguson

Mississippi State University

Brian J. Rude

Mississippi State University

D. Tommy King

USDA, Wildlife Services, National Wildlife Research Center, tommy.king@aphis.usda.gov

Follow this and additional works at: https://digitalcommons.unl.edu/icwdm_usdanwrc

Ferguson, Treena L.; Rude, Brian J.; and King, D. Tommy, "Nutrient Utilization and Diet Preference of American White Pelicans Consuming Either a Mono- or Multi-Species Diet" (2011). USDA National Wildlife Research Center - Staff Publications. 1318.

https://digitalcommons.unl.edu/icwdm_usdanwrc/1318

This Article is brought to you for free and open access by the U.S. Department of Agriculture: Animal and Plant Health Inspection Service at DigitalCommons@University of Nebraska - Lincoln. It has been accepted for inclusion in USDA National Wildlife Research Center - Staff Publications by an authorized administrator of DigitalCommons@University of Nebraska - Lincoln. 


\title{
Nutrient Utilization and Diet Preference of American White Pelicans Consuming Either a Mono- or Multi-Species Diet
}

\author{
Treena L. Ferguson ${ }^{1}$, Brian J. Rude ${ }^{1}$ AND D. TOMmy King ${ }^{2, *}$ \\ ${ }^{1}$ Department of Animal and Dairy Sciences, Mississippi State University, MS, 39762, USA \\ ${ }^{2}$ USDA, Wildlife Services, National Wildlife Research Center, Mississippi State, MS, 39762, USA \\ *Corresponding author: E-mail: Tommy.King@aphis.usda.gov
}

\begin{abstract}
American White Pelicans (Pelecanus erythrorhynchos) are reported to consume large quantities of commercial catfish in Alabama, Arkansas, Louisiana and Mississippi, negatively impacting aquaculture production. If pelicans consume a single item diet, such as catfish, nutritional deficiencies may result. Therefore, effects of monoand multi-species diets were examined to determine nutritional impacts on pelicans in addition to determining if preferences for certain fish species exist. Twelve American White Pelicans captured in northwest Mississippi were used for a seven day metabolism trial followed by a two day preference trial. In the metabolism trial, pelicans were assigned to one of three treatment diets (four birds/diet): catfish only, carp only, or both $(50 \%$ catfish and $50 \%$ carp). Pelicans consuming only catfish metabolized less dry matter, organic matter and energy than those consuming only carp or both. Four pelicans were used to determine preference for carp or catfish. Pelicans ate more $(\mathrm{P}=$ $0.001)$ carp (89\% of diet) and digested nutrients from carp more efficiently than they did from catfish. Pelicans can meet nutritional requirements by consuming a mono-species diet of fish; however, certain prey may be more beneficial and even preferred for consumption. Received 15 November 2010, accepted 5 April 2011.
\end{abstract}

Key words.-American White Pelican, carp, catfish, diet, metabolism, Pelecanus erythrorhynchos, preference.

Waterbirds 34(2): 218-224, 2011

Little information is available regarding the bioenergetics, nutrition and food preference of American White Pelicans (Pelecanus erythrorhynchos, AWPE) illustrating the need for more research in these areas. Daily maintenance requirements of AWPE have been estimated to be $10 \%$ of body mass ( 800 to $1500 \mathrm{~g}$ of fish as-fed basis; Guillet and Furness 1985; Johnsgard 1993). The energetic demands of wild pelicans have been reported to increase during times of breeding (Gremillet et al. 1995) and migration (Shmueli et al. 2000). Pelicans in the wild consume a variety of fish species, including Channel Catfish (Ictalurus punctatus) and Grass Carp (Ctenopharyngodon idella) (Guillet and Furness 1985; Johnsgard 1993; Shmueli et al. 2000; King 2005; King et al. 2010).

Pelicans metabolize nutrients from their fish prey with varying efficiencies. Pelican fecal and urinary products mix and exit the cloaca. Metabolism of nutrients accounts for urinary and fecal loss of nutrients post-consumption. Therefore, when collecting metabolic information on consumed fish species, excretions are used to determine metabolism, as digestibility only accounts for fecal excretion. Metabolism values reported are apparent because ap- parent metabolism assumes that what is metabolized only comes from the animals' diet, where true metabolism takes into account endogenous body losses. Derby and Lovvorn (1997) calculated dry matter metabolism of different fish species consumed by AWPE in Wyoming to range between 70 and 90\%. Similarly, Cooper (1980) reported Great White Pelican (Pelecanus onocrotalus) metabolism of rockfish to be $73 \%$.

More recently, AWPE have been reported to consume large numbers of farmed catfish (King 2005). In some cases, AWPE appear to be shifting to a mono-species diet (catfish) as opposed to a normal diet (multiple fish species). The energetic effects of such a dietary shift are unknown. Brugger (1993) suggested catfish may be less palatable to cormorants due to spiny fins, which may result in decreased intake. As a large portion of catfish is composed of bony material, there may be reduction in nutrient absorption, thus requiring an increased intake to meet energetic requirements. Fish bones, teeth and scales are organic material which is less digestible and primarily composed of collagen and phosphates (Degens et al. 1969). 
As AWPE digest various fish with a wide range of digestibilities, preferences for more energetically dense or more palatable fish may exist. Preferences for different riverine species of fish by AWPE have been reported by Derby and Lovvorn (1997). American White Pelicans preferred to consume suckers (Castastomus spp.) even when trout (Oncorhynchus mykiss) were much more abundant and readily available. Understanding prey preference for this species has implications for catfish aquaculture and captive management of AWPE. As little information exists about pelican metabolism of various fish species and preferences among species, the objectives of this study were to: 1) determine the nutritional content of Channel Catfish and Grass Carp; 2) determine nutrient metabolism of AWPE when fed a monospecies diet (Channel Catfish, Grass Carp) compared to a multi-species diet (50:50 mixture of Channel Catfish and Grass Carp); and 3) determine if AWPE demonstrate a preference for Channel Catfish or Grass Carp.

\section{METHODS}

Eighteen pelicans were captured in May 2009 from abandoned fish ponds near Belzoni, Humphreys County in northwest Mississippi using a rocket net and modified foot-hold traps (King et al. 1998). Twelve pelicans were selected for metabolism and preference trials. Following capture, birds were transported to the USDA/ WS National Wildlife Research Center's aviary on the Mississippi State University campus where the birds were placed into twelve individual pens $(3 \mathrm{~m}$ wide $\times 3 \mathrm{~m}$ high $\times 3 \mathrm{~m}$ long). Nine of the twelve birds were immature $(<3$ years old) and three were adults ( $\geq 3$ years old). Although the pelicans differed in age, all were within $90 \%$ of mean adult mass as reported by Dorr et al. (2005). The mean weight of the pelicans was 5,754 \pm 392 $\mathrm{g}$ at initiation of the trial. Reported means are $\pm \mathrm{SE}$. There was one female pelican in each of the three treatment groups (three females overall).

There was a ten-day acclimation period where $\sim 1,500$ $\mathrm{g}$ of catfish (five to ten whole, live fish) were fed to each pelican daily. Following the acclimation period, pelicans were placed in smaller metabolism cages for a seven-day metabolism trial. An additional two days were used, prior to the seven-day metabolism trial, to allow pelicans to adjust to the smaller cages and dietary treatments.

Smaller metabolism cages were used during the seven-day metabolism trial to decrease urine and fecal sample loss. Crates were equipped with a perch across the width of the crate to encourage birds to remain in the center of the crate. Smaller metabolism cages were designed to allow the pelican to extend its head and neck out into a feeding container without contaminat- ing total excreta. Metabolism crates $(1 \mathrm{~m}$ wide $\times 2 \mathrm{~m}$ long $\times 1.5 \mathrm{~m}$ high) had an $80 \mathrm{~mm}$ wide opening extending down one side of the crate allowing pelicans to extend only their bills and heads into a feeding bucket. Cages were constructed with wire mesh and wood. The floor of the cages was also wire mesh allowing feces and urine to fall through to fecal collection pans placed underneath.

Dietary treatments were Channel Catfish, Carp and a 50:50 mixture of both. The metabolism trial lasted for seven consecutive days, followed by a preference trial for an additional two days. After the preference trial the pelicans were weighed and the average of the beginning and ending body weight was used calculate intake data (McMeniman 2010). Each pelican had a single bucket ( 113 liters at 0.75 full) in which they received their dietary treatment each day for the duration of both trials (metabolism and preference). Both fish species were fed in a single bucket to reduce any selection bias. To decrease the influence of gastrointestinal tract contents of the fish on nutrient composition analyses, fish were not fed for at least one day prior to being fed to pelicans (Fountoulaki 2005).

This research was conducted in accordance with USDA/WS National Wildlife Research Centers' IACUC Approved Study Protocol QA-1650 (signed 6 April 2009; issued to T. King), U.S. Fish and Wildlife, Federal Fish and Wildlife Permit MB019065-2, and Mississippi Department of Wildlife, Fisheries, and Parks Scientific Collecting Permit.

\section{Metabolism Trial}

Pelicans were weighed and health was determined by a certified Mississippi State University veterinarian before placement into the metabolism crates. Twelve pelicans (nine male, three female) used in the metabolism trial were separated into three dietary treatment groups with four birds per group (three male, one female). The three dietary treatments were: 1) catfish; 2) carp; 3) 50:50 mixture of catfish and carp. Typically pelicans weighing $6 \mathrm{~kg}$ would be expected to consume $1,500 \mathrm{~g}$ of fish (King 2005). Therefore, regardless of body size, each bird received 1,500 g per day of their respective dietary treatment.

\section{Preference Trial}

Following the metabolism trial, four of the twelve pelicans (the four birds receiving the 50:50 mixture diet) were used in a preference trial. Each pelican was provided with 2,000 $\mathrm{g}$ of live catfish and 2,000 $\mathrm{g}$ of live carp daily in a single container ( 113 liters at 0.75 full). Because the protein and fat composition of fish changes with age, pelicans were fed catfish and carp at the same stage of maturity to ensure similar nutrient body composition. This resulted in a $350 \mathrm{~g}$ average body weight for catfish and a $75 \mathrm{~g}$ average body weight for carp. Expecting pelicans to require $1,500 \mathrm{~g}$ of food per day, 2,000 $\mathrm{g}$ of catfish and 2,000 $\mathrm{g}$ of carp were provided to allow for them to select diets depending upon their preference and not based on availability of either specie. Providing 2,000 g of each species of fish allowed pelicans the ability to obtain their daily food requirement by consuming all of either fish species if they chose to eat only one species. Each bird's daily allotment $(4,000 \mathrm{~g}$ total) of fish was provided in a single container. 
Laboratory Analysis

Feces, orts and samples of catfish and carp were dried at $60^{\circ} \mathrm{C}$ in a forced air oven. Dried fish, orts and excreta were ground to pass through a $2 \mathrm{~mm}$ screen of a Thomas Wiley Mill® (Author H. Thomas, Philadelphia, PA). All samples were analyzed for dry matter, organic matter, neutral detergent fiber, fat and crude protein using procedures described in AOAC (2003) and gross energy was determined using an isoperibol oxygen bomb calorimeter (Parr Instrument Co., Moline, IL).

\section{Statistical Analysis}

Data were subjected to analysis of variance using the general linear model procedures of SAS (Version 9.2, 1985). Individual pelicans were considered the experimental unit. Nutrient intake and nutrient metabolism analysis included treatment in the model statement. Preference trial analysis included treatment, replicate and interaction. When different $(\mathrm{P}<0.05)$ means were separated using Fisher's protected least significant difference.

\section{RESULTS}

\section{Metabolism Trial}

Nutritional composition of catfish and carp (Table 1) fed to AWPE was similar, except for neutral detergent fiber (NDF) and energy.

Pelican body mass and dry matter intake in each treatment are reported (Table 2). Body mass was calculated as the average of pre- and post- metabolism trial body mass. After the trial was conducted, mean body mass of pelicans $(\mathrm{N}=12)$ was $6,124 \pm 382.8$ $\mathrm{g}$, an increase of $370 \mathrm{~g}$ compared to the pretrial mass of $5754 \mathrm{~g} \pm$ 391.6. There were no differences $(\mathrm{P}=0.81)$ for body mass among the three different treatments (Table 2). Additionally, there were no differences $(\mathrm{P}>$ 0.05 ) among treatment groups for amount of dry matter consumed daily.

Although actual intake ( $\mathrm{g} /$ day) did not differ among treatments, daily intake with respect to body mass (\% $\mathrm{BM})$ was different
$(\mathrm{P}=0.01)$. Pelicans consuming the treatment of catfish only, consumed less fish $(4.4 \% \mathrm{BM})$ than pelicans receiving the treatments of carp only $(6.1 \% \mathrm{BM})$ or both $(5.1 \%$ $\mathrm{BM})$. Pelicans consuming the catfish only diet, proportional to body mass, ate the least amount of their respective treatment diet. Pelicans offered the dietary treatment of carp only, consumed more carp relative to body mass and also metabolized carp more efficiently (dry matter basis). Metabolism of catfish and carp presented in Table 3 is on a dry matter basis. Calculating these values to an as-fed basis (using \% moisture content) allows for a more practical application. Pelicans fed catfish (as-fed basis) consumed $20.6 \%$ of their body mass daily, pelicans fed carp consumed $24.3 \%$ of their body mass daily and pelicans fed the mixture of both consumed $22.1 \%$ of their body mass daily. During the trial pelicans fed both species of fish (50:50 mixture diet) did not consume all $1,500 \mathrm{~g}$ ( $750 \mathrm{~g}$ of catfish, and $750 \mathrm{~g}$ of carp) of their offered diet. Upon examining the ratio of what the pelicans did choose to consume, pelicans actually consumed $55 \%$ carp and $45 \%$ catfish.

Nutrient metabolism for pelicans consuming catfish was less than pelicans consuming carp or both. Dry matter metabolism was decreased $(\mathrm{P}=0.03)$ for pelicans consuming catfish only. Pelicans metabolized less $(\mathrm{P}=0.01)$ organic matter from the catfish only diet. Protein metabolism of catfish and/or carp was not different $(P=0.06)$. There were no differences $(\mathrm{P}=0.17)$ for neutral detergent fiber metabolism among the three treatment diets. Metabolism of fat and energy followed the same general trend as metabolism of dry matter and organic matter. Fat metabolism for pelicans consuming the catfish only diet averaged $71.9 \%$, which was $11.3 \%$ less than pelicans receiving

Table 1. Nutrient composition (DM basis) of catfish and carp fed to American White Pelicans $(\mathrm{N}=12)$. DM = dry matter, $\mathrm{OM}$ = organic matter, $\mathrm{CP}$ = crude protein, $\mathrm{NDF}$ = neutral detergent fiber.

\begin{tabular}{lcccccc}
\hline \hline & DM, $\%$ & OM, $\%$ & CP, $\%$ & NDF, $\%$ & FAT, $\%$ & Energy, kcal/g \\
\hline Catfish & 21.4 & 83.5 & 68.9 & 11.9 & 23.3 & 4694.1 \\
Carp & 24.9 & 86.2 & 67.1 & 4.6 & 25.4 & 5044.6 \\
\hline
\end{tabular}


Table 2. Dry matter intake and body mass of AWPE $(\mathrm{N}=12)$ consuming catfish and $/$ or carp. $\mathrm{DM}=$ dry matter. Both= diet offered consisted of $50 \%$ catfish and $50 \%$ carp.

\begin{tabular}{lccc}
\hline \hline Treatment & Body mass, $g$ & DM Intake, g/day & DM Intake, \% body mass/day \\
\hline Catfish & 6008 & 264.4 & $4.41^{\mathrm{a}}$ \\
Both & 5995 & 307.0 & $5.10^{\mathrm{a}}$ \\
Carp & 5689 & 341.7 & $6.06^{\mathrm{b}}$ \\
SEM & 384.2 & 22.45 & 0.296 \\
$\mathrm{~F}_{2,9}$ & 0.3 & 0.2 & 0.2 \\
$\mathrm{P}=$ & 0.81 & 0.10 & 0.01 \\
\hline
\end{tabular}

${ }^{\mathrm{a}, \mathrm{b}}$ Means with different superscripts within column differ $(\mathrm{P}<0.05)$.

the other treatment diets of both or carp only $(\mathrm{P}=0.06)$. Pelicans consuming catfish metabolized $7.9 \%$ less energy than birds consuming the 50:50 mixture or carp diets $(\mathrm{P}=$ $0.02)$.

\section{Preference Trial}

During the preference trial pelicans selected more $(\mathrm{P}=0.0001)$ carp $(\mathrm{BM} \sim 75 \mathrm{~g})$ than catfish (BM $\sim 350 \mathrm{~g}$; Table 4). Pelicans preferred the $(\sim 75 \mathrm{~g})$ carp, but did consume larger catfish, although less than the smaller carp. The amount of catfish consumed by pelicans was $246 \mathrm{~g}$ /day compared to 1,708 $\mathrm{g} /$ day of carp. Pelicans chose to consume $85 \%$ of the smaller carp and $12 \%$ of the larger catfish offered to them. Pelican diet composition (DM basis) was $89 \%$ carp and $11 \%$ catfish when allowed to choose between ad libitum large catfish and small carp.

\section{DISCUSSION}

The results of this study, in terms of daily fish consumption, were not dissimilar to pre- viously-reported study results. Previous exposure and consumption of catfish and carp by pelicans before being captured could not be determined, but should not have affected the results of this study. The nutritional composition of catfish and carp varied slightly in NDF content. However, as neutral detergent fiber is used to estimate overall available carbohydrates and as animals (and fish) are composed of very little carbohydrate, this difference was not expected to have a biological impact on results. The greater energy of catfish was due to the slightly greater fat content of catfish compared to carp.

During the metabolism trial pelicans provided with the catfish only diet (as-fed basis) consumed $\sim 20.6 \%$ of their body mass in fish each day. Pelicans offered the carp only diet (as-fed basis) consumed $\sim 24.3 \%$ of their body mass, and pelicans offered the mixture diet (as-fed basis) consumed $\sim 22.1 \%$ of their body mass in fish each day. These estimates are considerably more than the previously reported consumption of approximately $10 \%$ of body mass (as fed basis; Guillet and Furness 1984; Johnsgard 1993). However,

Table 3. Nutrient metabolism by AWPE $(\mathrm{N}=12)$ consuming catfish and/or carp. $\mathrm{DM}=$ dry matter, $\mathrm{OM}=$ organic matter, $\mathbf{C P}=$ crude protein, NDF = neutral detergent fiber. Both $=$ diet offered consisted of $50 \%$ catfish and $50 \%$ carp.

\begin{tabular}{|c|c|c|c|c|c|c|}
\hline Treatment & DM, \% & OM, \% & CP, \% & NDF, \% & FAT, $\%$ & Energy, \% \\
\hline Catfish & $42.2^{\mathrm{a}}$ & $52.0^{\mathrm{a}}$ & $2.5^{\mathrm{a}}$ & 93.9 & $71.9^{\mathrm{a}}$ & $74.4^{\mathrm{a}}$ \\
\hline Both & $54.8^{\mathrm{b}}$ & $64.1^{\mathrm{b}}$ & $22.5^{\mathrm{ab}}$ & 93.1 & $82.6^{\mathrm{b}}$ & $81.2^{\mathrm{b}}$ \\
\hline Carp & $60.0^{\mathrm{b}}$ & $68.0^{\mathrm{b}}$ & $28.1^{\mathrm{b}}$ & 90.1 & $83.7^{\mathrm{b}}$ & $83.4^{\mathrm{b}}$ \\
\hline SEM & 3.84 & 3.12 & 6.76 & 1.38 & 3.31 & 1.86 \\
\hline $\mathrm{F}_{2,9}$ & 5.6 & 7.2 & 0.7 & 3.9 & 2.1 & 6.3 \\
\hline $\mathrm{P}=$ & 0.03 & 0.01 & 0.06 & 0.17 & 0.06 & 0.02 \\
\hline
\end{tabular}

${ }^{\mathrm{a}, \mathrm{b}}$ Means with different superscripts within column differ $(\mathrm{P}<0.05)$. 
Table 4. Consumption of catfish and carp when both were offered to American White Pelicans $(\mathrm{N}=12)$. Consumed = amount of fish consumed, wet basis; $\%$ offered $=\mathrm{g}$ specie consumed $/ \mathrm{g}$ specie offered (i.e. $\mathrm{g}$ catfish consumed/ $2000 \mathrm{~g}$ catfish offered); $\%$ of diet $=\mathrm{g}$ specie consumed $/ \mathrm{g}$ total consumption.

\begin{tabular}{lccc}
\hline \hline Treatment & Consumed, /day & \% offered, $\%$ & $\%$ of diet, $\%$ \\
\hline Catfish & 246 & 12.26 & 10.76 \\
Carp & 1708 & 84.82 & 89.24 \\
SEM & 109.1 & 5.453 & 4.846 \\
$\mathrm{P}=$ & 0.0001 & 0.0001 & 0.0001 \\
\hline
\end{tabular}

this trial was conducted during May when energetic demands for migration and breeding have been reported to exceed $20 \%$ of body mass (as fed basis; Gremillet et al. 1995; Shumeli et al. 2000). Thus, the timing of this study and resultant higher energetic demands may explain the similarity in amount of fish (as-fed) consumed to the latter studies.

The metabolism of different fish species by pelicans reported in earlier studies may not account for what the fish had eaten prior to consumption (and thereby their gastrointestinal tract contents were consumed by pelicans). During our metabolism trial, fish went unfed for 24 hours prior to being fed to pelicans which may explain why apparent dry matter metabolism in the present study (42 to $60 \%$ ) was less than values previously reported (metabolism efficiencies) by pelicans; 70 to $90 \%$ for several species of fish (Derby and Lovvorn 1997). This explanation is supported by organic matter values reported in Table 3 as pelicans metabolized less organic matter from the catfish only diet $(\mathrm{P}=$ 0.01 ). Bones (as indicated by organic matter) of catfish and carp were a larger proportion of body composition (compared to soft tissue) because of an empty gastro-intestinal tract. The reduced consumption of catfish may be a result of decreased metabolism and increased regurgitation of bony non-nutritious material.

Another factor which may explain decreased consumption of catfish may be differences in the physical properties of the two fish species. During the trial pelicans experienced some difficulty consuming catfish due to their rigid spiny fins. Brugger (1993) reported similar difficulties with consumption of catfish by cormorants. Another physical factor which may have increased the pelicans' difficulty with, or reluctance to, swallow catfish was their larger size $(\sim 350 \mathrm{~g})$ compared to the carp ( $\sim 75 \mathrm{~g})$, used in this study. However, smaller carp may have been harder to catch inside the feeding container.

Pelicans consuming carp metabolized nutrients more efficiently than those consuming catfish (Table 3). Carp were smaller in size and therefore presented more surface area per mass which may have increased digestive efficiency. Additionally, catfish have a mucus layer over the skin's surface with a thicker epidermis than carp which may have made digestion by the pelican more difficult, thereby affecting nutrient metabolism (Maki and Dickerson 2003). Carp have a much thinner skin protected by scales and are not covered with a mucus layer; unlike catfish which have no scales. Scales may have reduced overall digestibility of carp (as scales are primarily composed of collagen and phosphates; Degens et al. 1969). However, even with the less digestible scales carp were more efficiently metabolized than catfish. Digestibility of carp scales relative to other fish scales is unknown.

There are several limitations to this study. Increased regurgitation and agitation of pelicans has been attributed to the presence of humans (Johnson and Sloan 1976; Boellstorff et al. 1988; Johnsgard 1993). The resulting increased distress may have decreased feed intake compared to wild (unconfined) pelicans (Uramoto 1961; Kale 1965; Willson and Harmenson 1973). Additionally, other factors such as confinement of birds and frequency of feeding may alter feed intake (Junor 1965, 1972; Brugger 1993). However, it is unlikely these possible issues are problematic to the interpretation of our study re- 
sults because obtaining actual metabolism was not the primary objective of this study. Because comparing the metabolism of the two different diets (fish) was the objective, the relative metabolism of each fish compared to the other was more important.

Although pelicans are considered opportunistic feeders (Johnsgard 1993), they have been reported to have preferences for certain fish species (Dunn 1975; Derby and Lovvorn 1997; King et al. 2010). Pelicans may consume a wide variety of readily available fish to meet their energetic demands even when they show a preference for certain fish species. During the metabolism trial, pelicans that were fed the mixture diet of approximately $750 \mathrm{~g}$ of catfish and $750 \mathrm{~g}$ of carp (receiving both large catfish and smaller carp), actually consumed $45 \%$ catfish and $55 \%$ carp. Pelicans were usually observed eating carp first and catfish afterwards. Although carp were preferred, pelicans still consumed catfish upon the depletion of carp. This ratio of actual consumption may be the result of not being provided enough of either species to consume only that species to meet their energetic demands. Also, individual catfish $(\sim 350 \mathrm{~g})$ used in the current study weighed more than the individual carp ( 75 g). Therefore, a preference for carp may be due to the ease of swallowing the smaller fish opposed to the catfish which were larger and had bony rigid fins.

These data suggest that both aquaculture and natural resource managers could refine pelican management strategies by creating alternative feeding sites for pelicans that will meet their energetic requirements. By developing and managing preferred feeding sites, pelicans may decrease predation on farmed catfish while gaining additional nutritional benefits of a multispecies diet. Further study is needed to determine how to best to preserve or re-create optimum foraging environments to be used for AWPE conservation and management.

When managing captive pelicans, it is beneficial to know which fish species provide the most nutrients. Although these results suggest that catfish, at least in the sizes of- fered in this study, may not be nutritionally optimum, pelicans readily consume large quantities of catfish at aquaculture facilities (King et al. 2010). Providing enhanced dietary quality for captive pelicans should save costs for managers and allow for more precise health management.

These data indicate AWPE have preferences for certain fish species at various sizes. These preferences may be due to physical properties of fish such as size, or rigid bony structure. Pelicans also metabolize some species of fish more efficiently which may also lead to preferences. Prey preferences of AWPE may also change seasonally. Although pelicans do have preferences for certain species of fish, they are still highly opportunistic and will consume less preferred fish if readily available to fulfill energetic demands. Preference for certain species of fish may allow deterrence from predation of farmed catfish by establishing large fish densities or preferred sizes in areas away from aquaculture ponds. Seasonal shifts of forage preference may also help explain and predict pelican migration patterns.

\section{ACKNOWLEDGMENTS}

We thank S. Demarais and J. Belant for assistance with the project design. We also thank C. Altman, S. Bowers, C. Dunnaway, P. Fioranelli, J. Greene, S. Lemmons, A. Mitchell, A. Leed, B. Oloyede and P. Ryan for help with capture, feeding and sample analysis.

\section{Literature Cited}

AOAC. 2003. Official Methods of Analysis, (17th Ed.) Association of Official Analytical Chemists, Arlington, Virginia.

Boellstorff, D. E., D. W. Anderson, H. M. Ohlendorf and E. J. O'Neill. 1988. Reproductive effects of nestmarking studies in an American White Pelican colony. Colonial Waterbirds 11: 215-219.

Brugger, K. E. 1993. Digestibility of three fish species by Double-crested Cormorants. Condor 95: 25-32.

Cooper, J. 1980. Energetic requirements for maintenance of a captive juvenile Great White Pelican (Pelecanus onocrotalus). Cormorant 8: 17-19.

Dorr, B. S., D. T. King, J. B. Harrel, P. Gerard and M. G. Spalding. 2005. The use of culmen length to determine sex of American White Pelicans (Pelecanus erythrorhynchos). Waterbirds 28 (Special Publication 1): 102-106.

Degens, E. T., W. G. Druser and R. L. Haedrich. 1969. Molecular structure and composition of fish otoliths. Marine Biology 2: 105-113. 
Derby, C. E. and J. R. Lovvorn. 1997. Predation on fish by cormorants and pelicans in a cold-water river: A field and modeling study. Canadian Journal of Fisheries and Aquatic Science 54: 1480-1493.

Dunn, E. H. 1975. Caloric intake of nestling Doublecrested Cormorants. Auk 92: 553-565.

Fountoulaki, E., M. N. Alexis, L. Nengas and B. Venou. 2005. Effect of diet composition on nutrient digestibility and digestive enzyme levels of Gilthead Sea Bream (Sparus aurata L.). Aquaculture Research 36: 1243-1251.

Gremillet, D., D. Schmid and B. Culik. 1995. Energy requirements of breeding Great Cormorants Phalacrocorax carbo sinensis. Marine Ecology Progress Series 121: 1-9.

Guillet, A. and R. W. Furness. 1985. Energy requirements of Great White Pelican (Pelicanus onocrotalus) population and its impact on fish stocks. Journal of Zoology (London) 205: 573-583.

Johnsgard, P. A. 1993. Cormorants, Darters, and Pelicans of the world. Smithsonian Institution Press. Washington, D.C.

Johnson, Jr., R. F. and N. F. Sloan. 1976. The effects of human disturbance on the White Pelican colony at Chase Lake National Wildlife Refuge, North Dakota. Inland Bird Banding News 48: 163-170.

Junor, F. J. R. 1965. Hand-rearing of birds of piscivorous type in the Kariba and Lake Kyle areas of Southern Rhodesia. International Zoology Yearbook 5: 155-162.

Junor, F. J. R. 1972. Estimations of the daily food intake of piscivorous birds. Ostrich 43: 193-205.

Kale, H. W., II. 1965. Ecology and bioenergetics of the Long-billed Marsh Wren in Georgia saltmarshes. Nuttall Ornithology Club Publication No. 5.
King, T. D., J. D. Paulson, D. J. Leblanc and K. Bruce. 1998. Two capture techniques for American White Pelicans and Great Blue Herons. Colonial Waterbirds 21: 258-260.

King, D. T. 2005. Interactions between American White Pelicans and aquaculture in the southeastern United States: An overview. Waterbirds (Special Publication 1) 28: 83-86.

King, D. T., J. Belant, B. Harrel and J. Glahn. 2010. Superabundant food at catfish aquaculture facilities improves body condition in American White Pelicans. Waterbirds 33: 221-227.

Maki, J. L. and H. W. Dickerson. 2003. Systemic and cutaneous mucus antibody responses of Channel Catfish immunized against parasite Ichthyophthirius multifiliis. Clinical and Diagnostic Laboratory Immunology 10: 876-81.

McMeniman, J. P., L. O. Tedeschi, P. J. Defoor and M. L. Galyean. 2010. Development and evaluation of feeding-period average dry matter intake prediction equations from a commercial feedlot database. Journal Animal Science 88: 3009-3017.

Shmueli, M., I. Izaki, A. Arieli and Z. Arad. 2000. Energy requirements of migrating Great White Pelicans Pelecanus onocrotalus. Ibis 142: 208-216

Statistical Analysis Systems Institute. 1985. SAS User guide. (Version 9.2) SAS Institute Incorporated. Cary, North Carolina.

Uramoto, M. 1961. Ecological study of the bird community of the broad-leaved deciduous forest of central Japan. Yamashina Institution Ornithology 3: 1-32.

Willson, M. F. and J. C. Harmenson. 1973. Seed preferences and digestive efficiencies of cardinals and Song Sparrows. Condor 75: 225-233. 